\title{
PENGARUH MODEL PEMBELAJARAN INQUIRYTERBIMBING TERHADAP PEMAHAMAN KONSEP KIMIA SISWA DI MAN 2 KOTA BIMA TAHUNPELAJARAN 2019/2020
}

\author{
Nurfidianty Annafi, Magfirah Perkasa, Sry Agustina, Putri Ayu Mutmainnah, Ela \\ Purnama Sari
}

${ }^{1}$ Program Studi Pendidikan Kimia STKIP BIMA

Email: nurfidianty89@gmail.com

\begin{abstract}
ABSTRAK
Telah dilakukan penelitian tentang pengaruh model pembelajaran inquiry terbimbing terhadap pemahaman konsep kimia siswa di MAN 2 Kota Bima tahun pelajaran 2019/2020. Tujuan utama penelitian adalah apakah ada pengaruh model pembelajaran inquiry terbimbing terhadap pemahaman konsep kimia siswa di MAN 2 Kota Bima tahun pelajaran 2019/2020. Popoulasi dalam penelitian ini adalah seluruh kelas X IPA . sedangkan sampelnya kelas X IPA ${ }^{1}$ sebagai kelas kontrol dan X IPA ${ }^{2}$ sebagai kelas eksperimen dengan jumlah siswa 45 orang dan $X$ IPA $^{2}$ sebagai kelas kontrol dengan jumlah siswa 45 orang. Instrumen yang digunakan pada penelitian ini berupa tes (pretest dan posttest). Untuk mengetahui tingkat kemampuan pemahaman konsep siswa dilakukan dengan menggunakan uji Mann Whitney $U$ dengan bantuan SPSS versi 16. Berdasarkan hasil analisis data bahwa nilai rata-rata siswa kelas eksperimen adalah 89,67 sedangkan kelas kontrol sebesar 84,51. Perbandingan antara kedua nilai rata-rata tersebut terlihat jelas bahwa nillai rata-rata tersebut terlihat jelas bahwa nilai rata-rata kelas eksperimen jauh lebih besar dibandingkan kelas kontrol. Berdasarkan hasil data yang dihitung dengan menggunakan uji Mann Whitney $U$ dengan bantuan SPSS versi 16 dengan taraf signifikasi $<0,05 \mathrm{H}_{0}$ ditolak sebaliknya jika nilai Asymp. Sig. $>0,05$, maka $\mathrm{H}_{a}$ diterima dengan nilai signifikan Asymp. Sig. (2tailed) sebesar -,557. Maka dapat disimpulkan dalam penelitian ini terdapat pengaruh model pembelajaran inquiry terbimbing terhadap pemahaman konsep kimia siswa di MAN 2 Kota Bima.
\end{abstract}

Kata Kunci: Inquiry terbimbing, konsep kimia, siswa MAN 2 KOBI

\section{PENDAHULUAN}

Fungsi pendidikan adalah membimbing anak kearah suatu tujuan yang kita nilai tinggi. Pendidikan yang berkualitas mampu menghasilkan sumber daya manusia yang berkualitas juga, tidak hanya itu pendidikan pada dasarnya adalah usaha sadar yang dapat mengembangkan potensi diri seseorang, sehingga terbentuklah kepribadian dan keterampilan yang baik yang dapat berguna bagi dirinya sendiri, masyarakat dan negara. Upaya dalam meningkatkan mutu pendidikan adalah usaha yang dilakukan oleh pemerintah, antara lain peningkatan kualitas pendidikan guru, mengadakan sarana dan prasarana serta melaksanakan perubahan kurikulum. Guru sebagai tenaga pendidik memegang peranan utama dan sebagai ujung tombak dalam proses belajar mengajar (Depdiknas, 2003).

Seiring dengan perkembangan ilmu pengetahuan dan teknologi, kimia sebagai salah satu ilmu dasar yang semakin dirasakan kegunaannya untuk kalangan umum, namun pada kenyataan belajar kimia bagi sebagian orang sangat rumit dan kurang menarik. Hal tersebut banyak disebabkan selama ini konsep-konsep kimia lebih sering disampaikan oleh pendidik 
kepada peserta didk sebagai fakta bukannya sebagai peristiwa atau gejala alam yang harus diamati, diukur dan didiskusikan. Masih terlalu banyak pendidik berpikir bahwa mengajar adalah pemindahan pengetahuan (hafalan) dari pendidik yang merasa maha mengetahui kepada peserta didik. Sesuai dengan hasil observasi di MAN 2 Kota Bima tahun pelajaran 2019/2020.

Berdasarkan hasil observasi awal peneliti di sekolah MAN 2 Kota Bima, bahwa hasil belajar kimia kelas X MAN 2 Kota Bima tahun pelajaran 2019/2020 tergolong rendah. Hal ini terlihat dari nilai rata-rata skor belajar siswa satu tahun terakhir mencapai 60,00 . Hasil nilai rata-rata tersebut belum mencapai standar kompetensi yang telah ditentukan dalam kriteria ketuntasan minimal mata pelajaran kimia. Sedangkan nilai KKM yang ditentukan oleh sekolah tersebut adalah 75,00 .

Rendahnya hasil belajar kimia, disebabkan oleh beberapa faktor: 1) Penyampaian materi kimia oleh guru dengan metode demonstrasi yang hanya sekali-kali dan diskusi cenderung membuat siswa jenuh, siswa hanya dijejali informasi yang kurang konkrit dan diskusi yang kurang menarik karena bersifat teoritis. 2) Siswa tidak pernah diberi pengalaman langsung dalam mengamati suatu benda, sehingga siswa menganggap materi pelajaran kimia adalah abstrak dan sulit difahami. 3) Metode mengajar yang digunakan guru kurang bervariasi dan tidak inovatif, sehingga membosankan dan tidak menarik minat siswa. Hal ini menunjukkan kompetensi guru kimia yang masih perlu ditingkatkan.

Khususnya mata pelajaran kimia dalam proses belajar mengajar, metode dan pendekatan yang digunakan dalam satu konsep belum tentu cocok dengan konsep lain karena metode atau pendekatan yang digunakan dalam proses belajar mengajar masing-masing memiliki kelebihan dan kekurangan. Hal ini dapat terungkap melalui peningkatan pemahaman siswa terhadap suatu konsep sesuai bahan ajar yang diajarkan (Trianto, 2007). Salah satu model pembelajaran yang relevan dan sesuai dengan permintaan kurikulum adalah Model Pembelajaran Inquiry Terbimbing. Hanafiah (2010) Inquiry adalah suatu rangkaian kegiatan pembelajaran yang melibatkan secara maksimal seluruh kemampuan peserta didik untuk mencari dan menyelidiki secara sistematis, kritis dan logis sehingga mereka dapat menemukan sendiri pengetahuan, sikap dan keterampilan sebagai wujud adanya perubahan prilaku.

Berdasarkan pendapat di atas dapat disimpulkan, bahwa model pembelajaran Inquiry terbimbing merupakan model pembelajaran yang memberikan kesempatan kepada peserta didik untuk aktif terlibat dalam proses pembelajaran dengan melakukan penyelidikan dan pemecahan masalah secara mandiri namum tetap dengan bimbingan pendidik agar peserta didik lebih mudah dalam memahami konsep pelajaran.

Pemahaman berasal dari kata paham yang menurut Kamus Besar Bahasa Indonesia (Depdiknas, 2008) berarti pengertian, pendapat; pikiran, aliran; haluan; pandangan, mengerti benar (akan); tahu benar (akan), pandai dan mengerti benar (tentang suatu hal). Aziz dan Rahmat (2009) mengartikan pemahaman dalam konteks terapan adalah proses atau hasil dan upaya seseorang untuk mendapatkan makna dari teks tertulis atau lisan Sedangkan dalam kurikulum adalah proses atau hasil dari upaya siswa untuk menguasai materi yang ada dalam suatu pengajaran.

Menurut Purwanto (2010) pemahaman atau komprehensi adalah tingkat kemampuan yang mengharapkan sesorang mampu memahami arti atau konsep, situasi, serta fakta yang 
diketahuinya. Seseorang tersebut tidak hanya hafal secara verbalistis, tetapi memahami konsep dari masalah atau fakta yang dinyatakan. Berdasarkan pendapat dari beberapa ahli tersebut, peneliti dapat menyimpulkan bahwa pemahaman konsep merupakan suatu proses kemampuan menangkap makna dan arti dari bahan atau materi yang dipelajari.

Istilah konsep menurut Poewardaminta (2007) adalah sebuah rancangan. Hasil abstraksi yang diperoleh melalui pengamatan terhadap sejumlah gejala. Sedangkan menurut Azis dan Rahmat (2009) konsep adalah penggambaran abstrak tentang kejadian, keadaan, kelompok atau individu. yang menjadi pusat perhatian ilmu sosial. Berdasarkan pendapat dari beberapa ahli tersebut, jadi dapat disimpulkan bahwa arti dari pemahaman konsep adalah suatu proses untuk menangkap makna gambaran dari beberapa objek atau kejadian yang sesungguhnya.

\section{METODE PENELITIAN}

Jenis penelitian ini adalah penelitian eksperimen, berupa quasi-experiment design dengan jenis rancangan yang digunakan adalah non equivalent control group design. Adapun rancangan yang dimaksud dapat dilihat pada tabel 1 berikut :

Tabel 1. Non Equivalent Control Group Design
\begin{tabular}{|l|l|l|l|}
\hline Kelas & $\begin{array}{l}\text { Pre } \\
\text { test }\end{array}$ & Treatment & $\begin{array}{l}\text { Post- } \\
\text { test }\end{array}$ \\
\hline Eksperimen & $0_{1}$ & $\mathrm{X}$ & $\mathrm{O}_{2}$ \\
\hline Kontrol & $0_{3}$ & $\mathrm{X}$ & $0_{4}$ \\
\hline
\end{tabular}

Keterangan:

$0_{1}$ : Hasil pre test pada kelas eksperimen.

$0_{3}$ : Hasil pre test pada kelas kontrol.

$\mathrm{X}$ : Pemberian perlakuan pada kelas eksperimen berupa model pembelajaran discovery learning.

$0_{2}$ : Hasil post-test pada kelas eksperimen.

04: Hasil post-test pada kelas kontrol (Sugiyono, 2010).

Populasi pada penelitian ini adalah seluruh siswa kelas X IPA MAN 2 Kota Bima tahun pelajaran 2019/2020 yang terdiri dari 5 kelas. Sampel yang digunakan pada penelitian ini adalah sebanyak 2 kelas, pengambilan sampel menggunakan teknik non probabillity sampling dengan jenis puposive sampling.

Analisis data dilakukan untuk memecahkan permasalahan pada rumusan masalah dan menguji hipotesis penelitian yang diajukan, untuk mempermudah dalam melakukan pengolahan data, semua pengujian statistik pada penelitian ini dilakukan dengan menggunakan bantuan software SPSS versi 16 for windows. Adapun analisis data yang dilakukan adalah:

\section{Uji Prasyarat}

\section{Uji Normalitas}

Uji normalitas bertujuan untuk mengetahui apakah data dari kedua kelompok berdistribusi normal atau tidak. Uji normalitas yang digunakan dalam penelitian ini adalah dengan menggunakan Shapiro-Wilk test dengan taraf signifikasi 0,05. 
$\mathrm{H}_{0}$ diterima jika nilai sig (p) dari Shapiro-Wilk $>0,05$ dan terima $\mathrm{H}_{\mathrm{a}}$ jika nilai sig ( $\mathrm{p}$ ) dari Shapiro-Wilk $<0,05$.

\section{Uji Homogenitas}

Uji ini dilakukan untuk mengetahui apakah sampel yang dibandingkan memiliki nilai rata-rata dan varians identik. Uji homogenitas yang digunakan dalam percobaan ini adalah levene statistics test dengan taraf signifikasi 0,05.Terima $\mathrm{H}_{0}$ jika nilai sig $(\mathrm{p})$ dari Levene Statistics test $>0,05$ dan terima $\mathrm{H}_{\mathrm{a}}$ jika nilai sig (p) dari Levene Statistics $<0,05$.

\section{Uji Hipotesis}

Setelah melakukan uji prasyarat, selanjutnya melakukan uji hipotesis. Apabila sampel berasal dari populasi yang berdistribusi normal dan sampel mempunyai variansi yang homogen, maka uji hipotesis dilakukan menggunakan uji t. Apabila sampel berasal dari populasi yang normal tetapi sempel mempunyai variansi yang tidak homogen maka uji $\mathrm{t}$ masih berlaku, namun jika sampel tidak berdistribusi normal dan sampel mempunyai variansi homogen maka uji yang dilakukan adalah uji non parametrik yaitu uji Mann Whitney. Berikut rumusan hipotesis yang diajukan:

$\mathrm{H}_{0}$ : tidak ada pengaruh model pembelajaran Inquiry terbimbing terhadap pemahaman konsep siswa kelas X pada materi teori atom di MAN 2 Kota Bima.

$\mathrm{H}_{\mathrm{a}}$ : ada pengaruh model pembelajaran Inquiry terbimbing terhadap pemahaman konsep siswa kelas X pada materi teori atom di MAN 2 Kota Bima.

\section{HASIL}

Data yang diambil dari kedua kelas berupa data awal (pre-test) dan data akhir (post-test) sesuai dengan desain penelitian yang digunakan. Setelah semua data terkumpul diperlukan adanya analisis data. Sebelum menganalisis data peneliti terlebih dahulu melakukan tes, adapun yang diukur dalam penelitian ini adalah pemahaman konsep siswa, maka tes yang digunakan yaitu tes non objektif berupa tes uraian sebanyak 5 butir soal. Soal ini diberikan kepada siswa yang menjadi sampel penelitian di kelas X IPA 1 (kelas kontrol) dan kelas X IPA 2 (kelas eksperimen).

Setelah diberikan perlakuan (kegiatan proses belajar mengajar selesai). Siswa diberikan posttest guna untuk mengukur sejauh mana mereka dapat memahami pelajaran yang telah diajarkan. Adapun nilai rata-rata posttest kelas eksperimen sebesar 89,67 dan kelas kontrol sebesar 84,51. Berdasarkan perhitungan statistik dengan bantuan software SPSS versy 16 for windows maka diperoleh data sebagaimana yang tertera pada tabel berikut:

Tabel 2. Nilai Pemusatan dan Penyebaran Pemahaman Konsep Siswa Berdasarkan Posttest

\begin{tabular}{|l|l|l|l|l|l|}
\hline \multicolumn{5}{|c|}{ Descriptive Statistics } \\
\hline & $\mathrm{N}$ & Minimum & Maximum & Mean & $\begin{array}{l}\text { Std. } \\
\text { Deviation }\end{array}$ \\
\hline $\begin{array}{l}\text { Kelas } \\
\text { Ekperimen }\end{array}$ & 45 & 73 & 100 & 89,67 & 86,76 \\
\hline kelas kontrol & 45 & 60 & 100 & 84,51 & 82,06 \\
\hline
\end{tabular}


Berdasarkan tabel 2 dapat diketahui bahwa pada kelas eksperimen nilai terendah siswa sebesar 73, nilai tertinggi sebesar 100 , nilai rata-rata sebesar 89,67 . Sedangkan pada kelas kontrol nilai terendah siswa sebesar 60, nilai tertinggi sebesar 100, nilai rata-rata sebesar 84,51.

Tabel 3 Hasil Uji Normalitas Kelas Eksperimen Berdasarkan Nilai Posttest Siswa

\begin{tabular}{|l|l|l|l|l|}
\hline \multirow{2}{*}{$\begin{array}{l}\text { Pemahaman } \\
\text { Konsep }\end{array}$} & \multicolumn{3}{|l|}{ Shapiro-Wilk } & \multirow{2}{*}{ Keterangan } \\
\cline { 2 - 5 } & Statistic & Df & Sig & \\
\hline Eksperimen & 0,205 & 45 & 0,000 & $\begin{array}{l}\text { Tidak } \\
\text { Normal }\end{array}$ \\
\hline Kontrol & 0,194 & 0,001 & $\begin{array}{l}\text { Tidak } \\
\text { Normal }\end{array}$ \\
\hline
\end{tabular}

Berdasarkan tabel diatas dapat disimpulkan bahwa data posttest kelas eksperimen maupun kelas kontrol tidak normal karna nilai sig $<0,05$, yaitu kelas eksperimen memperoleh nilai sig. 0,000 dan kelas kontrol sebesar 0,001. Uji homogenitas dilakukan pada kelas eksperimen dan kelas kontrol dengan data sebagai berikut:

Tabel 4. Uji Homogenitas Kelas Eksperimen dan Kelas Kontrol Berdasarkan Nilai Posttest.

\begin{tabular}{|l|l|l|l|}
\hline $\begin{array}{l}\text { Levene } \\
\text { Statistic }\end{array}$ & df1 & df2 & Sig. \\
\hline 2,232 & 6 & 37 &, 062 \\
\hline
\end{tabular}

Berdasarkan tabel di atas, dapat disimpulkan bahwa data dari kedua kelas memiliki variansi yang homogen karena nilai signifikan > 0,05, yaitu nilai sig. sebesar 0,062.

Setelah melakukan uji prasyarat dengan menggunakan uji normalitas dan homogenitas, selanjutnya dilakukan uji hipotesis. Uji hipotesis dilakukan menggunakan uji Mann Whitney $U$ dengan bantuan SPSS versi 16. Pengujian hipotesis menggunakan uji ini dilakukan karena data tidak terdistribusi normal meskipun sampel tergolong homogen. Taraf signifikasi yang digunakan pada uji Mann Whitney adalah >0,05. Pengambilan keputusannya adalah jika nilai Asymp. Sig. > 0,05 maka $\mathrm{H}_{0}$ diterima, sebaliknya jika nilai Asymp. Sig. < 0,05, maka $\mathrm{H}_{0}$ ditolak. Hasil uji hipotesis yang dilakukan dapat dilihat pada tabel berikut:

Tabel 5. Hasil Uji Hipotesis Berdasarkan Data Posttest Pada Kelas Eksperimen Dan Kelas

\begin{tabular}{|l|l|}
\multicolumn{2}{|c|}{ Kontrol } \\
\hline Test Statistics $^{\mathbf{a}}$ & $\begin{array}{l}\text { Pemahaman } \\
\text { konsep siswa }\end{array}$ \\
\hline Mann-Whitney U & 946,500 \\
\hline Wilcoxon W & 1981,500 \\
\hline Z &,- 557 \\
\hline
\end{tabular}




\begin{tabular}{|l|l|}
\hline Asymp. Sig. (2-tailed) &, 578 \\
\hline $\begin{array}{l}\text { a. Grouping Variable: kelas eksperimen } \\
\text { dan kelas kontrol }\end{array}$ \\
\hline
\end{tabular}

Dari tabel diatas diperoleh nilai sig. di konsulkasikan dengan taraf signifikan Sig.> 0,05 maka $\mathrm{H}_{0}$ diterima, sebaliknya jika nilai Asymp. Sig. $<0,05$, maka $\mathrm{H}_{0}$ ditolak dan $\mathrm{H}_{\mathrm{a}}$ diterima.. Dengan demikian dapat dikatakan bahwa $\mathrm{H}_{a}$ diterima yaitu tidak ada perbedaan rata-rata pemahaman konsep siswa antara kelas eksperimen dan kelas kontrol pada materi teori atom,yaitu memperoleh nilai sig. sebesar 0,578. Artinya tidak ada pengaruh model pembelajaran inquiry terbimbing terhadap pemahaman konsep kimia siswa di MAN 2 Kota Bima tahun pelajaran 2019/2020.

\section{PEMBAHASAN}

Penelitian ini dilaksanakan dengan tujuan untuk mengetahui pengaruh model pembelajaran inquiri terbimbing terhadap pemahaman konsep kimia siswa MAN 2 Kota Bima dengan materi Teori Atom. Dalam penelitian ini banyak sampel yang diambil adalah 90 siswa dengan 45 siswa sebagai kelas eksperimen dan 45 siswa sebagai kelas kontrol. Penelitian ini termasuk penelitian quasi eksperimen karena penelitian ini bertujuan untuk mengetahui apakah ada pengaruh model pembelajaran inquiri terbimbing terhadap pemahaman konsep dengan cara memberikan perlakuan (treatment) pada kelas eksperimen. Prosedur penelitian yang dilaksanakan pada penelitian ini adalah dengan menggunakan metode demonstrasi, ceramah dan tanya jawab untuk melihat sejauh mana siswa dapat mengetahui suatu konsep dalam kimia. Sedangkan prosedur penelitian yang dilaksakan pada kelas kontrol dengan menggunakan metode ceramah (metode konvensional).

Beberapa hal yang mendukung penerapan keberhasilan dalam proses kegiatan belajar mengajar dengan menggunakan model inquiry terbimbing dalam meningkatkan pemahaman konsep yaitu mengamati, mengkomunikasikan,mengklarisifikasikan dan menyimpulkan, inilah yang membantu siswa dalam mengembangkan suatu pemahaman konsep belajar. Menggunakan model pembelajaran inquiry terbimbing yang merupakan pembelajaran yang menggunakan pendekatan ilmiah dan inquiry. Dalam pelaksanaan proses pembelajaran kelas eksperimen menggunakan model inquiry terbimbing pada materi teori atom siswa dituntut untuk mengembangkan keterampilan intelektual dan keterampilan-keterampilan lainnya dengan mengajukan pertanyaan dan menemukan atau mencari tahu sendiri jawaban dari keingintahuan mereka dengan menggunakan LKS (Lembar Kerja Siswa).

Berdasarkan hasil analisis deskripsi, menunjukkan bahwa pemahaman konsep kimia siswa pada materi Teori Atom mengalami peningkatan yang cukup signifikan dengan diterapkannya model pembelajaran inquiri terbimbing tersebut. Hal ini dapat dilihat dari perbedaan nilai rata-rata baik untuk rata-rata pretest maupun rata-rata pretest pada kelas eksperimen maupun kelas kontrol. Setelah dilakukan pengolahan data secara statistik yaitu dengan melakukan uji prasyarat yang terdiri dari uji normalitas dan uji homogentitas, pada pengolahan data uji normalitas menunjukkan bahwa data tidak terdistribusi normal dan pada pengolahan data uji homogen pretes maupun pretest sampel bervariansi homogen. Untuk rata- 
rata pretest pada kelas eksperimen bernilai 18,75 sedangkan pada kelas kontrol bernilai 20,62. Dan rata-rata posttest, bernilai 89,67 untuk kelas eksperimen, dan 84,51 untuk kelas kontrol. Oleh karena itu Analisis deskriptif pemahaman konsep dilakukan dengan menggunakan uji Mann Whitney dengan menunjukkan nilai asym sig. untuk pretes sebesar 0,05 dan untuk pretest sebesar 0,578. .

Analisis deskripsi pengujian hipotesis yang dilakukan guna melihat pengaruh pembelajaran inquiri terbimbing terhadap pemahaman konsep kimia siswa dengan menggunakan uji Man Withney. Data yang diperolah dari hasil uji tersebut sebesar 0,578 dengan taraf signifikan (a) =0,05 yang berarti uji hipotesis diterima. Dengan demikian dapat disimpulkan bahwa tidak terdapat pengaruh model pembelajaran inquiri terbimbing terhadap pemahaman konsep kimia siswa kelas X IPA² MAN 2 Kota Bima tahun pelajaran 2019/2020, dikarenakan: 1) Rendahnya kemampuan guru dalam penyampaian materi pembelajaran. 2) Tingkat kemampuan individual siswa rendah. 3) Tingkat reliabilitas soal tergolong rendah.

Hasil yang diperoleh dalam penelitian ini adalah a) siswa mampu mengembangkan potensi yang dalam diri mereka yang ditunjukkan dengan menjawab soal yang telah diajukkan. b) siswa dapat memahami konsep-konsep pembelajaran dalam kimia. Setiap proses pembelajaran tidak selamanya berlangsung baik dan sesuai yang diharapkan. Berdasarkan identifikasi ketika proses pembelajaran bahwa lemahnya kemampuan siswa dalam belajar kimia bukan hanya disebabkan karena siswa tidak bisa memahami konsep yang berikan tetapi juga karena model serta metode pembelajaran yang digunakan terlalu monoton sehingga cenderung bersifat membosankan serta kemampuan guru dalam menyampaikan materi pembe lajaran dapat juga mempengaruhi terhadap peningkatan hasil belajar siswa. Hal ini akan berpengaruh secara langsung terhadap kemampuan siswa dalam pembelajaran tersebut

\section{KESIMPULAN}

Berdasarkan hasil analisis dan pengujian hipotesis dapat ditarik kesimpulan bahwa tidak terdapat pengaruh model pembelajaran Inquiri Terbimbing Terhadap Pemahaman Konsep Kimia Siswa MAN 2 Kota Bima tahun pelajaran 2019/2020. Hal ini terbukti dari hasil perhitungan data dengan menggunakan uji Mann Whitney dengan menunjukkan nilai asym sig. untuk pretes sebesar 0,005 dan untuk posttest sebesar 0,578.

\section{DAFTAR PUSTAKA}

Arikunto, S. 2013. Prosedur Penelitian: Suatu Pendekatan Praktis. Jakarta: Rineka Cipta.

Aziz dan Rahamat. 2009. Psikolog Pendidikan: Model Pengembangan Kreativitas Dalam Praktek Pembelajaran. Malang: UIN- MALIKI PRESS (Anggota IKAPI).

Basrowi, S. 2007. Metode Analisis Data Sosial. Kediri: CV Jenggala Pustaka Utama.

Depdiknas, RI. 2003. UU No. 20 Tahun 2003 Tentang Sistem Pendidikan Nasional. Jakarta: Depdiknas.

Depdiknas, RI. 2008. Panduan Pengembangan Bahan Ajar. Jakarta: Depertemen Pendidikan Nasional.

Eggn Paul, dan D. Kauchak. 2009. Strategi dan Model Pembelajaran. Bandung: Pustaka Pelajar. 
Erinosho, S.Y. 2013. How do students perceive the difficulty of physics in secondary school? An exploratory study in Nigeria. International journa for Cross-Disciplinary Subjects in Education (IJCDSA), 3,3. Diambil pada tanggal 2 juni 2019, dari http://infonomicssociety.org.wp-content/uploads/ijcdse/published-papers/special-issue-volume-32013/How-Do-Students-Perceive-the-difficuly-of-Physics-in-Secondary-School.pdf.

Fraenkel, J. R. and Wallen, N.E. 2009. How to Design and Evaluate Researchin Education (7th ed.). Boston: Mc Graw-Hill.

Giancoli, Douglas. 2001. Fisika. Jakarta: Earlangga.

Hamalik, O. 2006. Proses Belajar Mengajar. Bandung: Bumi Askara.

Hamiyah, N. Dan M. Jauhar. 2014. Strategi Belajar Mengajar Di Kelas. Jakarta: Prestasi Pustaka. Hamruni. 2012. Strategi Pembelajaran.Yogyakarta: Insan Madani.

Hanafiah, Nanang, dkk. 2010. Konsep Strategi Pembelajaran. Bandung: PT Refika Aditama.

Kulhlthau, C Carol. 2006. Guided Inquiri Learning In The I" Century Westpot. CT: Libraries Unlimited.

Nana Sudjana. 2013. Dasar-dasar Proses Belajar Mengajar. Bandung: Sinar Baru Algensindo.

Ngalimun. 2012. Strategi dan Model Pembelajaran. Banjarmasin: Aswaja Pressindo.

Paidi. 2007. Peningkatan Scientific Skill Siswa Melalui Inplementasi Metode Guided Inquiry Pada Pembelajaran Biologi di SMAN 1 Sleman. Diakses dari http://staff.uny.ac.id/20Paidi/UNY.pdf pada 02 Juni 2019 Poewadarminta. 2007. Kamus Besar Bahasa Indonesia. Jakarta.

Purwanto. 2010. Evaluasi Hasil Belajar. Yogyakarta: Pustaka Pelajar

Sanjaya, Wina. 2010. Strategi Pembelajaran Berorientasi Standar Proses Pendidikan. Jakarta: Prenada Media Group.

Sudjana, N. 2002. Metode Penelitian. Bandung: Tarsito.

Sudjana, Nana. 2008. Penelitian Hasil Proses Belajar Mengajar. Bandung: Remaja Rosdakarya.

Sudijono, Anas. 2009. Pengantar Evaluasi Pendidikan. Jakarta: Raja Grafindo.

Sudujono, Anas. 2009. Pengantar Statistik Pendidikan. Jakarta: Rajawali Pers.

Sugiyono. 2012. Statistik Untuk Penelitian. Bandung: Alfabeta.

Sumarwan dkk. 2007. IPA SMP untuk Kelas VII. Jakarta: Earlangga.

Suryosubroto, B. 2009. Proses Belajar Mengajar Di Kelas. Jakarta: PT Rineka Cipta.

Trianto, S. 2007. Model-Model Pembelajaran Inovatif Berorientasi Konstruktivistik.. Jakarta: Prestasi Pustaka. 